\title{
ON THE REVERSE YOUNG AND HEINZ INEQUALITIES
}

\author{
Mohammad Bagher Ghaemi, Nahid Gharakhanlu \\ AND SHIGERU FURUICHI
}

Abstract. In this paper, we study further improvements of the reverse Young and Heinz inequalities for positive real numbers. We use these modified inequalities to obtain corresponding operator inequalities and matrix inequalities on the Hilbert-Schmidt norm.

Mathematics subject classification (2010): 15A15, 15A42, 15A60, 47A30, 47B45.

Keywords and phrases: Reverse Young inequality, reverse Heinz inequality, positive real numbers, positive operators, Hilbert-Schmidt norm, operator inequality.

\section{REFERENCES}

[1] M. BAKHerad And M. S. Moslehian, Reverse and variations of Heinz inequality, Linear Multilinear Algebra., doi: 10.1080/03081087.2014.880433.

[2] R. BHATIA, Interpolating the arithmetic-geometric mean inequality, SIAM J. Matrix Annal. Appl., 14, (1993), 132-136.

[3] S. Furuichi, On refined young inequalities and reverse inequalities, J. Math. Inequal., 5, 1 (2011), 21-31.

[4] S. Furuichi, Refined Young inequalities with Specht's ratio, J. Egyptian Math. Soc., 20, (2012), $46-49$.

[5] T. FURUTA AND M. YANAGIDA, Generalized means and convexity of inversion for positive operators, Amer. Math. Monthly., 105, (1998), 258-259.

[6] T. FuRUTA, Invitation to Linear Operators: From Matrix to bounded linear operators on a Hilbert space, Taylor and Francis, 2002.

[7] T. Furuta, J. MićIĆ Hot, J. PeČArić, Mond-Pečarić Method in Operator Inequalities, Element, Zagreb, 2005.

[8] F. Hial, Matrix Analysis: Matrix monotone functions, matrix means and majorization, Interdisciplinary Information Science., 16, (2010), 139-248.

[9] O. Hirzallah and F. KitTaneh, Matrix Young inequalities for the Hilbert-Schmidt norm, Linear Algebra Appl., 308, (2000), 77-84.

[10] O. Hirzallah, F. Kittaneh, M. Krnić, N. LovričEviĆ and J. Pečarić, Eigenvalue inequalities for differences of means of Hilbert space operators, Linear Algebra Appl., 436, (2012), 15161527.

[11] F. Kittaneh And M. KRnić, Refined Heinz operator inequalities, Linear Multilinear Algebra., 61, (2013), 1148-1157.

[12] F. Kittaneh, M. Krnić, N. LovričEvić And J. PeČArić, Improved arithmetic-geometric and Heinz means inequalities for Hilbert space operators, Publ. Math. Debrecen., 80, (2012), 465-478.

[13] F. Kittaneh AND Y. ManasRah, Improved Young and Heinz inequalities for matrices, J. Math. Anal. Appl., 361, (2010), 262-269.

[14] F. KitTANeh AND Y. MANASRAh, Reverse Young and Heinz inequalities for matrices, Linear Multilinear Algebra., 59, (2011), 1031-1037.

[15] H. Kos AKI, Positive definiteness of functions with applications to operator norm inequalities, Memoirs of the American Mathematical Society 997, 2011.

[16] M. KRNIĆ, N. LOVRIČEVIĆ AND J. PEČARIĆ, Jensen's operator and applications to mean inequalities for operators in Hilbert space, Bull. Malays. Math. Sci. Soc., 2, 35 (2012), 1-14. 
[17] F. Kubo And T. Ando, Means of positive operators, Math. Ann., 264, (1980), 205-224.

[18] J. MIĆIĆ, J. PEČARIĆ AND V. ŚIMIĆ, Inequalities involving the arithmetic and geometric means, Math. Inequal. Appl., 3, 11 (2008), 415-430.

[19] J. ZHAO AND J. WU, Operator inequalities involving improved Young and its reverse inequalities, J. Math. Anal. Appl., 421, (2015), 1779-1789.

[20] H. L. Zuo, G. H. SHI AND M. FujiI, Refined Young inequality with Kantorovich constant, J. Math. Inequal., 5, (2011), 551-556. 